Box 2: Reasons for obtaining consent

- Research on tissue can harm patients by disclosing health or other information resulting in discrimination in employment or insurance (breach of confidentiality)

- Patients may have values regarding research, especially commercial research or genetic research (see box 1). Research may be a "consequence material to the patient's consent"

- Seeking consent promotes public confidence in medicine and research, prevents exploitation, and regulates the behaviour of researchers

- It may benefit participants by allowing the identity of participants to be known and results with implications for the health of participants to be reported to them (and their families)

- It may benefit researchers by allowing further information and samples to be gathered from participants and to link databases

- It allows sensitivity to be shown towards cultural values

- It empowers research participants and may enable them to share in profits of research

persons by educating them, by being open, and by giving them the chance to express themselves and their values. Every consent form for medical procedures should include reference to the possibility of research being conducted on redundant tissue and the patient should be given an opportunity to express any objections to this.

This should not be seen as a substitute for consent but rather as a way of alerting researchers to people who have some kind of objection to research. This should not be a carte blanche for ethics committees to approve future research, but it will be one factor among others for the committee to decide whether specific consent will be required.

\section{The duty of easy rescue}

One of the most basic moral duties is the "duty of easy rescue": when the benefits to others of a person performing some act are significant and the cost to that person is minimal, then he or should perform the act. People should have a beneficent attitude to the use of tissues excised or removed as a part of their clinical care. But morality should not be enforced. The best way to enhance the bank of tissues available for research is through education and encouraging people to donate their redundant tissues to research, not by requiring it or taking them without their knowledge.Julian Savulescu

Competing interests: None declared.

1 Marshall E. Families sue hospital, scientist for control of Canavan gene Science Online 2000;290(5494):1062 reprinted as: Who controls and who benefits from human genetics research? Monash Bioethics Review 2001;20:50.

2 Moore $v$ Regents of the University of California 202 Cal App 3d 1230, 249 Cal Rptr 494 (1988); 51 Cal 3d 120, 793P 2d, 479, 271 Cal Rptr 146 (1990).

3 www.health.gov.au/nhmrc/publications/synopses/e35syn.htm

\section{Corrections and clarifications}

Health can take precedence over trade issues, says report In this news article by Sanjay Kumar (31 August, p 460), as a result of an editing error, we said that Miguel Rodriguez Mendoza was the principal coordinator of the joint study by the World Trade Organization (WTO) and the World Health Organization. We should have said that he was the principal coordinator of the study for the WTO only (not for both organisations).

\section{This Week in the BMJ}

The bar chart illustrating one of the summary paragraphs at the start of the $B M J$ on 31 August ("Patients' characteristics determine consultation length") showed the wrong values for mean consultation length. The graph was based on a table that appears in the full (bmj.com) version of the paper (by Myriam Deveugele and colleagues, pp 472-4). In converting the table to a graph we inadvertently used the standard deviation values rather than the mean values. From left to right the values of the bars should be 7.6, 7.8, 9.4, 10.2, 15.0, 15.6, and 10.7. The table on bmj.com is correct.

Career focus

At the start of the "Profile" article in the BMJcareers supplement (20 July, p s22) we said that Elaine Griffiths was the first female cardiothoracic surgeon in Britain. We have since heard that Miss Betty V Slesser was a cardiothoracic surgeon from the 1950s. We apologise for any offence caused.

\title{
My first patient
}

I was 10 years old when I found that I had head lice. I lived with my aunt then and was too ashamed to tell her. I searched the medicine cabinet but found nothing promising. The oil lamp in the bathroom held a remedy, and I massaged my scalp with paraffin. The next problem was to get rid of the paraffin. A hot bath transferred the paraffin to the rest of my body and left a thin film over the bath. More soap and water got rid of it eventually. About a week later I developed swellings at the back of the neck. The doctor was called, and when he asked if I had been scratching my head my shame was complete.

Eight years later, my non-medical roommate developed swellings in the neck and was not pleased with my provisional diagnosis of head lice. His displeasure turned to scorn when he was taken away to the fever hospital with rubella.

I liked to think that this taught me the danger of hasty diagnosis.

D W Smith retired general practitioner, Podington, Wellingborough

We welcome articles up to 600 words on topics such as A memorable patient, A paper that changed my practice, My most unfortunate mistake, or any other piece conveying instruction, pathos, or humour. If possible the article should be supplied on a disk. Permission is needed from the patient or a relative if an identifiable patient is referred to. 